\title{
Tiller density and tillering on Brachiaria brizantha $c v$. Marandu pastures inoculated with Azospirillum brasilense
}

\author{
[Densidade populacional e perfilhamento em pastagens de Brachiaria brizantha $\mathrm{cv}$. \\ Marandu inoculada com Azospirillum brasilense] \\ B.C. Pedreira ${ }^{1}$, P.L. Barbosa ${ }^{2}$, L.E.T. Pereira ${ }^{3}$, M.A. Mombach ${ }^{2}$, L.F. Domiciano ${ }^{2}$, \\ D.H. Pereira ${ }^{2}$, A. Ferreira ${ }^{1}$ \\ ${ }^{1}$ Embrapa Agrossilvipastoril - Sinop, MT \\ ${ }^{2}$ Universidade Federal de Mato Grosso - UFMT - Sinop, MT \\ ${ }^{3}$ Universidade de São Paulo - USP - Pirassununga, SP
}

\begin{abstract}
The objective of this study is to verify the population density and the dynamics of tillering in the Marandu palisade grass sward subjected to nitrogen $(\mathrm{N})$ fertilization strategies, characterized by the $\mathrm{N}$ supply via urea or bacterial inoculant (Azospirillum brasilense). The treatments comprised of four nitrogen fertilization strategies: (A) Without fertilization, (B) $80 \mathrm{~kg} \mathrm{~N} / \mathrm{ha}$, (C) inoculant (A. brasilense), and (D) 80 $\mathrm{kg} \mathrm{N} / \mathrm{ha}+$ inoculant, distributed in a randomized complete block design, with three replications. The nitrogen supply strategies were evaluated during six periods: October, November, and December (2012) as well as January, March, and April (2013). The nitrogen dose or inoculant had no effect on the tiller appearance rate (TAR), tiller mortality rate (TMR), tiller survival rate (TSR), or tiller population density (TPD). However, these variables were influenced by the season. The TAR and TSR were higher at the beginning of the experimental period (October) and lower towards the end of the period (March-April), whereas, TMR and TPD exhibited the opposite behavior, with lower values in October and higher from January onward. Neither the nitrogen nor the inoculant influenced the population dynamics of the tillers in Marandu palisade grass.
\end{abstract}

Keywords: diazotrophic bacteria, nitrogen biological fixation (NBF), stability index, tillers, urea

\section{RESUMO}

Objetivou-se com este estudo verificar a densidade populacional e a dinâmica do perfilhamento em dosséis de capim Marandu submetidos a estratégias de adubação nitrogenada, caracterizadas pelo fornecimento de $N$ via ureia ou inoculante (Azospirillum brasilense). Os tratamentos foram quatro estratégias de adubação nitrogenada: sem fertilização, $80 \mathrm{~kg} \mathrm{~N} / \mathrm{ha}$, inoculante (A. brasilense) e $80 \mathrm{~kg} \mathrm{~N} / \mathrm{ha}$ + inoculante, distribuídos em um delineamento de blocos completos ao acaso, com três repetições por tratamento. As estratégias de aporte nitrogenado foram avaliadas em seis épocas: outubro, novembro e dezembro de 2012; e janeiro, março e abril de 2013. Não foi verificada influência da dose de nitrogênio ou do inoculante sobre a taxa de aparecimento (TAP), a taxa de mortalidade (TMP), a taxa de sobrevivência (TSP) e a densidade populacional de perfilhos (DPP). No entanto, essas variáveis foram influenciadas pela época do ano. A TAP e a TSP apresentaram maiores valores no início do período experimental (outubro) e menor valor ao final do período (março a abril). A TMP e a DPP expressaram respostas opostas, com menores valores em outubro e maiores a partir de janeiro. Não houve influência do nitrogênio e do inoculante sobre a dinâmica populacional de perfilhos em capim Marandu.

Palavra-chave: FBN, bactérias diazotróficas, ureia, perfilhos, índice de estabilidade

Recebido em 27 de setembro de 2016

Aceito em 10 de outubro de 2016

E-mail: bruno.pedreira@embrapa.br 


\section{INTRODUCTION}

Bacteria belonging to genus Azospirillum were isolated from the rhizosphere of many grasses and cereals globally, in tropical as well as in temperate climates, as their utility as plant growth promoting rhizobacteria has been advocated for many years (Smith et al., 1984; Steenhoudt and Vanderleyden, 2000). They are free-living nitrogen-fixing bacteria and once they reveal versatile Carbon (C) and $\mathrm{N}$ metabolism, they possess low energy requirements (Tilak and Annapurna, 1993). This enables them to adapt and become well-established in the competitive environment of the rhizosphere (Steenhoudt and Vanderleyden, 2000).

The beneficial effects of Azospirillum inoculation in cereals reported in the literature, include, more vigorous vegetative growth, with greater shoot and dry root matter accumulation (Díaz-Zorita and Canigia, 2009), higher N accumulation (Sala et al., 2007), and higher grain yield (Sala et al., 2007; Hungria et al., 2010). They also help to minimize the effects of waterstress (Casanovas et al., 2002). Their contribution estimated in terms of the $\mathrm{N}$ fixed by the diazotrophic bacteria in grasses like corn, wheat, and rice is between 25 and $50 \mathrm{~kg}$ $\mathrm{N} / \mathrm{ha} /$ year, an equivalent of an average supply of $17 \%$ of the nitrogen demand of these crops (Silva et al., 2004).

These responses have kindled an increased interest in their use as bacterial inoculants in pastures as well. Nitrogen biological fixation (NBF) through the endophytic diazotrophic bacteria such as $A$. brasilense, is an effective alternative to minimize the use of nitrogenous fertilizers, as these, besides their high cost, can cause serious environmental problems, such as, water and soil contamination with nitrates (Campos et al., 2003). Smith et al., (1984) working on Sorghum bicolor (L.) Moench (sorghum), and the interspecific hybrid between Pennisetum americanum (L.) K. Schum. (pearl millet), and $P$. purpureum Schumach. (napier grass) in field inoculation experiments conducted in Florida and New Mexico, indicated that other mechanisms besides NBF could mediate plant growth. The production of plant growthpromoting substances such as auxins and the increase in the rate of mineral uptake by the plant roots are as important in establishing plant responses as the NBF (Tilak and Annapurna, 1993; Steenhoudt and Vanderleyden, 2000; Dobbelaere et al., 2003).

The persistence and productivity of tropical grasses are ensured by the constant replenishment of the $P$. purpureum Schumach. individuals in the population (Silva et al., 2008). Therefore, the ability of the plant to produce new tillers directly affects the population density and the grazing adaptability (Hodgson, 1990). Given that the duration of life of the tillers is limited, with grazing being one of the main causes of its mortality, the combined benefits of utilizing $A$. brasilense mentioned above could augment tillering in the tropical grasses cited under grazing conditions. In this context, the objective of this study was to determine the isolated or combined effect of $\mathrm{N}$ supply via urea and/or a bacterial inoculant (A. brasilense) on the population density and tillering dynamics in Marandu palisade grass sward (Brachiaria brizantha cv. Marandu).

\section{MATERIAL AND METHODS}

The experiment was conducted in Embrapa

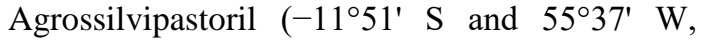
elevation of $370 \mathrm{~m}$ ), in partnership with the Universidade Federal de Mato Grosso (UFMT), between the months of October 2012 and March 2013 in grasslands of Brachiaria brizantha (Syn. Urochloa brizantha) cv. Marandu, established in 2011.

The soil in the area was classified as clayey dystrophic hapludox with $465 \mathrm{~g} / \mathrm{dm}^{3}$ of clay in flat relief, revealing the following chemical characteristics in the $0-20 \mathrm{~cm}$ layer at the beginning of the experiment: $\mathrm{pH}=4.54\left(\mathrm{CaCl}_{2}\right)$; organic matter $=28.54 \mathrm{~g} / \mathrm{dm}^{3} ; \mathrm{P}=3.14 \mathrm{mg} / \mathrm{dm}^{3} ; \mathrm{K}$ $=16 \mathrm{mg} / \mathrm{dm}^{3} ; \mathrm{Ca}=1.15 \mathrm{cmol}_{\mathrm{c}} / \mathrm{dm}^{3} ; \mathrm{Mg}=$ $0.44 \mathrm{cmol}_{\mathrm{c}} / \mathrm{dm}^{3} ; \mathrm{H}+\mathrm{Al}=3.8 \mathrm{cmol}_{\mathrm{c}} / \mathrm{dm}^{3}$; sum of the bases $=1.63 \mathrm{cmol}_{\mathrm{c}} / \mathrm{dm}^{3}$; cation exchange capacity $(\mathrm{pH} 7.0)=5.3 \mathrm{cmol}_{\mathrm{c}} / \mathrm{dm}^{3} ;$ base saturation $=30.02 \%$. Assuming this as the reality from the perspective of soil fertility of the grassland in the area, no alterations were made.

The climate was classified according to the criteria of Köppen, as Am - monsoon climate, which alternates between a rainy and a dry season (Alvares et al., 2013), with annual 
average temperatures exceeding $24^{\circ} \mathrm{C}$ and rainfall of about $1900 \mathrm{~mm}$ (Fig. 1).

The treatments involved four nitrogen supply strategies: without nitrogen fertilization, $80 \mathrm{~kg}$
$\mathrm{N} /$ ha, only one bacterial inoculant (A. brasilense) and $80 \mathrm{~kg} \mathrm{~N} / \mathrm{ha}+$ bacterial inoculant. These were distributed in a randomized complete block, with three replications, where each repetition included a plot of $30 \mathrm{~m}^{2}(5 \times 6 \mathrm{~m})$, totaling 12 plots.

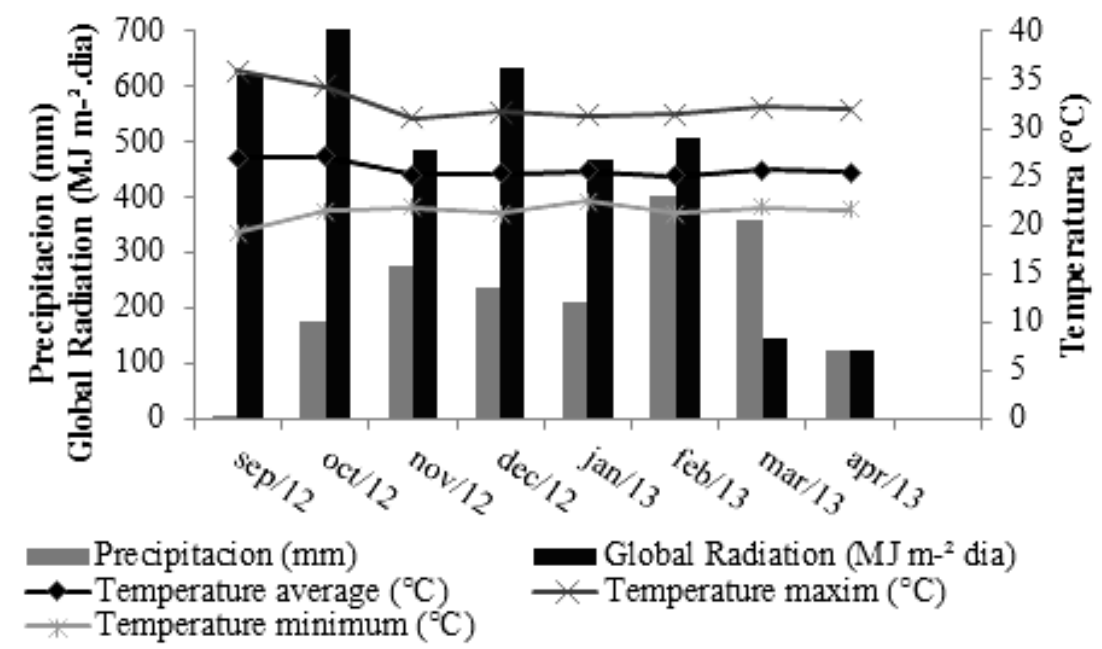

Figure 1. Data monthly rainfall, solar radiation, and maximum temperature, average and minimum during the trial period

In September of 2012, all plots were harvested at a height of $7 \mathrm{~cm}$ and fertilizer was applied totaling $80 \mathrm{~kg} / \mathrm{ha}$ Phosphorus $\left(\mathrm{P}_{2} \mathrm{O}_{5}\right), 40 \mathrm{~kg} / \mathrm{ha}$ Potassium $\left(\mathrm{K}_{2} \mathrm{O}\right)$, in forms of Superphosphate and Potassium Chloride $(\mathrm{KCl})$, respectively. Nitrogen fertilization was fractioned in two postharvest applications. The first nitrogen supply corresponded with the application of $40 \mathrm{~kg} \mathrm{~N} / \mathrm{ha}$ and the second fertilization $(40 \mathrm{~kg} \mathrm{~N} / \mathrm{ha}+40 \mathrm{~kg}$ $\mathrm{K}_{2} \mathrm{O} /$ ha) occurred between February 21, 2013 and March 13, 2013. Urea was used as the $\mathrm{N}$ source, and to avoid the volatilization effect, it was dissolved in $30 \mathrm{~L}$ of water and uniformly distributing throughout the plot by manual watering.

For the diazotrophic bacteria to colonize the plant tissues, the inoculum was introduced postharvest, when there were openings or injuries on the leaves and stems. In the inoculated plots, $A$. brasilense bacteria $\left(2 \times 10^{8}\right.$ colony forming unit $(\mathrm{CFU}) / \mathrm{mL}$ ), of the Ab-V5 and Ab-V6 strains in particular, were used at a dose of $500 \mathrm{~mL} / \mathrm{ha}$. The inoculant was applied in the late afternoon, as a foliar spray, with a spray volume of 150 $\mathrm{L} / \mathrm{ha}$. A second application of the inoculum was performed in the fifth production cycle, on the same date of the nitrogen fertilization, always post harvest, to guarantee infection by the bacteria at the harvest tissues .

The plots were harvested when $25 \mathrm{~cm}$ of sward height was achieved, leaving a residue of $7 \mathrm{~cm}$ height (Lara and Pedreira, 2011). To characterize forage accumulation, two quadrat samples $(0.5$ by $1 \mathrm{~m}$ ) were clipped per plot. They were subsequently dried at $55^{\circ} \mathrm{C}$ in a forced air dryer until constant weight. Assessments regarding population density and the dynamics of tillering were always performed in the post-harvest condition, in the months of October, November, and December (2012); and January, March, and April (2013).

To calculate the TSR and population stability index (SI), the TAR and TMR had to be determined and expressed as tillers (100 tillers $\times$ 30 days) (Caminha et al., 2010). For this purpose, three Polyvinyl chloride (PVC) rings were used in each experimental unit, $30 \mathrm{~cm}$ in diameter, fixed in the ground with metal staples, in areas classified as representing the average pasture conditions.

In the first evaluation, all the tillers within the respective rings, both basal as well as air, were marked off with shielded wires using specific 
colored plastic. In the second evaluation, only the existing living tillers in the sampling rings, derived from the first mark, were re-counted and the new ones, which appeared between the sampling periods, were measured and identified by using threads different in color from the earlier one. From number of measurements of the tiller of each generation, in each evaluation, the balance between the appearance and death of the tillers was calculated, enabling the TSR to be determined by the equation TSR $=100$ (number of tillers previously marked and living in the current marking / total number of live tillers in the previous marking) (Bahmani et al., 2003).

The population SI, based on the relationship between TSR and TAR was obtained by applying the following equation: Fp/Ip = TSR (1 + TAR), wherein: Fp/Ip corresponds to the final population (Fp) expressed as a percentage of the initial population (Ip) of tillers in a specific evaluation period; and TSR and TAR are the tiller survival and appearance rates, respectively, during the same period. When the index is equal to 1 , the number of tillers is balanced and stable. Values below 1 indicate that the pastures have compromised their stability and imply that the number of tillers tends to decrease, as the appearance of new tillers would not be sufficiently large in number relative to the mortality, to maintain the density. Moreover, values greater than 1 indicate an upward trend in the number of tillers (Bahmani et al., 2003).

Assessment of the TPD was performed by counting the total number of tillers contained within a rectangle of $0.32 \mathrm{~m}^{2}(0.8 \times 0.4 \mathrm{~m})$. These were released at random in the representative sites having average conditions in their plots, following the visual assessment of height and forage mass (Fialho et al., 2012).

Statistical analysis was performed using the linear mixed models with repeated measures, employing the ML (maximum likelihood) methodology by means of PROC MIXED the statistical package SAS® (Statistical... 2013), version 8.2 for Windows ${ }^{\circledR}$. All data sets were tested for normality of error distribution and homogeneity of the variances. In cases where the normal distribution of errors had not been checked, processing was performed according to the display suggested by SAS®. The matrix of the variance and covariance were tested and the choice was based on the Bayesian information criterion (BIC). The treatment effect was considered fixed and the block was considered to be the random effect, whereas, the time of year was considered to be the repeated measure over time. The correction of the degrees of freedom was performed using the method of Kenward and Roger (1997) - DDFM $=$ KR. The treatment means were estimated using the "LSMEANS" and the comparison between them, if necessary, was performed by the probability of the difference (PDIFF) and error probability of $10 \%$.

\section{RESULTS AND DISCUSSION}

The forage accumulation, TAR, TMR, and TSR rates, did not differ between the $\mathrm{N}$ input strategies $(\mathrm{P}>0.10)$, but were rather influenced by the season $(P<0.10$ for all the variables $)$. In the present study, despite the application of a nitrogen fertilizer and the use of a bacterial inoculant, other nutrients may have limited forage accumulation. Thus, it can be assumed that the use of an inoculant did not reduce the necessity of soil correction to guarantee forage growth. Forage accumulation was affected by the season, were raining months registered higher values (Fig. 2). Furthermore, the values obtained in this experiment are lower than those observed by Souza et al. (2016) in Marandu palisade grass pasture inoculated with $A$. brasilense in Oxisol dystrophic soils, which contributes to the previous assumption.

From the commencement of the experiment in October, the harvest of standardization promoted the increased light availability for the sward base, which combined with the availability of the growth factors (Fig. 1) resulted in the greatest TAR values recorded over the evaluation period (Fig. 3 A). 


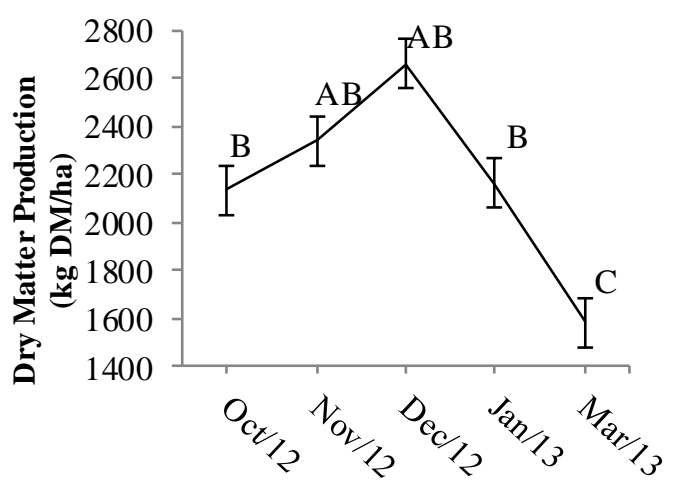

Figure 2. Forage accumulation (kg DM/ha) of Marandu palisade grass pastures. Means followed by the same letter do not differ $(\mathrm{P}>0.10)$. Vertical bars represent the standard error of average.
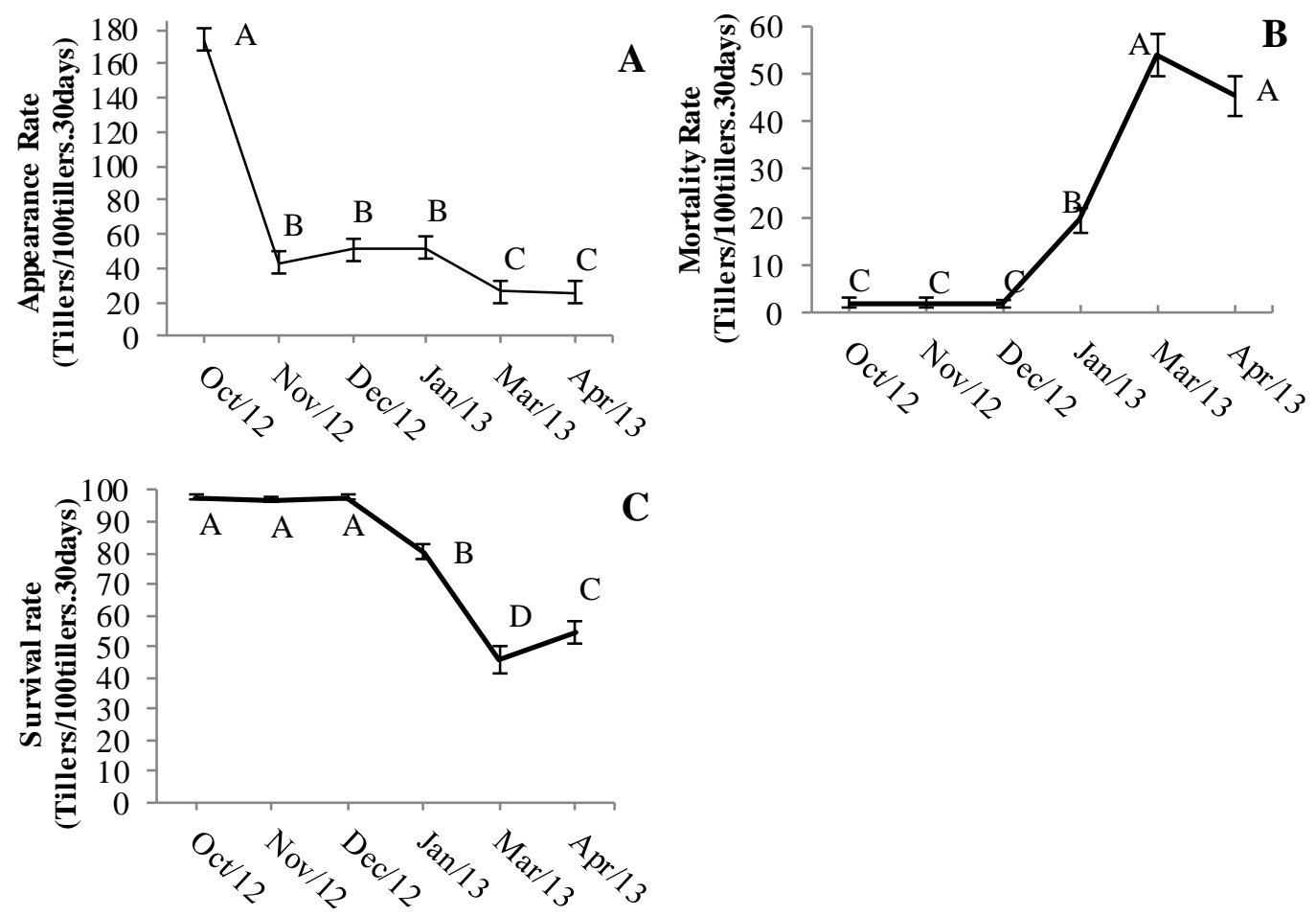

Figure 3. Appearance (A), mortality (B), and survival rate (C) (tillers/100 tillers $\times 30$ days) in Marandu palisade grass pastures. Means followed by the same letter do not differ $(\mathrm{P}>0.10)$. Vertical bars represent the standard error of average.

The TSR of the generations produced in early spring remained high until December, resulting in low values for the TMR (Figs. $3 \mathrm{~B}$ and C). From January 2013, the survival of the population of individuals began to decline, therefore, that the highest TMR values were recorded in March and April. These variations in the dynamics of the tillers between the evaluation months interfered with the population SI $(\mathrm{P}<0.0001)$, reaching values of less than 1 in March and April (Fig. 4), and the tiller population density (TPD, P<0.0001) (Fig. 5). 


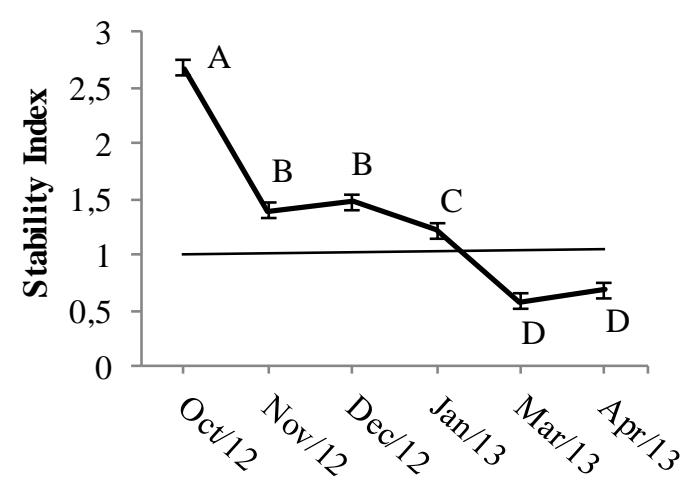

Figure 4. Stability index of tiller population Marandu palisade grass pastures. Means followed by the same letter do not differ $(\mathrm{P}>0.10)$. Vertical bars represent the standard error of average

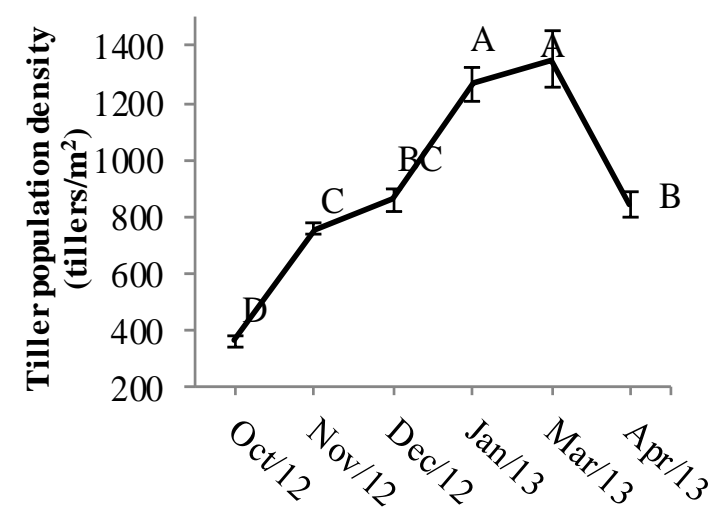

Figure 5. Tiller population density (tillers $/ \mathrm{m}^{2}$ ) in Marandu palisade grass pastures. Means followed by the same letter do not differ $(\mathrm{P}>0.10)$. Vertical bars represent the standard error of average

In general, SI values less than 1 indicate that in a given period the appearance rates are relatively lower than the tiller survival rates, revealing the instability of the plant population in the plant communities (Sbrissia, 2004). The average solar radiation recorded in February corresponded to $508 \mathrm{MJ} / \mathrm{m}^{2}$, which drastically dropped to $143 \mathrm{e}$ $123 \mathrm{MJ} / \mathrm{m}^{2}$, respectively, in March and April. These light intensity variations act as modulators of plant responses and flags, to cause changes in the growth stages (Taiz and Zeiger, 2013), inducing the beginning of the reproductive period. Thus, the allocation of resources for the activation and development of buds gets reduced, resulting in a lower TAR, which combined with the increase in the mortality of tillers, contributes to a decrease in the SI. Fialho et al., (2012) demonstrated a similar pattern of variation in population dynamics in the Marandu palisade grass swards, managed under a rotational stocking of 25 or $35 \mathrm{~cm}$ pre-grazing height and receiving 50 or $200 \mathrm{~kg} \mathrm{~N} / \mathrm{ha}$, with decreases in
TAR from February. Likewise, Caminha et al., (2010) recorded an SI below 1 in autumn, winter, and early spring on the Marandu palisade grass swards, managed under continuous stocking, and this pattern of variation was independent of the $\mathrm{N}$ dose (non-fertilized or fertilized with 150,300 or $450 \mathrm{~kg} \mathrm{~N} / \mathrm{ha})$.

As a result of the changes in the appearance and mortality of the individuals registered in late summer and early autumn, a decrease in the tiller population density (TPD) was observed in April $2013\left(840 \pm 21.18\right.$ the tillers $\left./ \mathrm{m}^{2}\right)$. According to Silva et al., (2015), periods of high availability of climatic growth factors (e.g., temperature and rainfall), as in late spring and summer, are characterized by high rates of tiller appearance and death, and therefore, short-lived generations. However, the balance between the tiller appearance and death is usually positive and results in an increased tiller population density. This is corroborated by the increase in TPD from 
October to March (Fig. 5). During autumn/winter and early spring the tiller survival increases, although not enough to offset a reduction in the tiller appearance, and the density of the tiller population decreases. Such variations in the tillering dynamics represent a natural cycle of plant growth throughout the year, and they occur regardless of the grazing strategy, grazing method, and fertilization level (Caminha et al., 2010; Silva et al., 2015).

According to Matthew et al., (2000), many grass species appear to have programmed seasonal patterns of tiller birth and death, which may be referred to as perennation strategies. Knowledge regarding the perennation strategy for particular cultivars or species can enable the identification of management and fertilization strategies that will improve their productivity, through the enhancement of the natural cycle of tiller replacement. In the Brazilian conditions, autumn, winter, and early spring seasons are characterized by a drop in temperature, radiation, and precipitation. The intense water deficit paralyzes growth and increases plant mortality. Steenhoudt and Vanderleyden (2000) reported that Azospirillum inoculation promotes alterations in root morphology and architecture, which includes an increased number of lateral roots and root hairs, thus enlarging the root surface available for nutrient absorption. This results in a higher nutrient uptake by the inoculated roots, and thus, an improved water status of the plant. Based on these facts, the strategic supply of $\mathrm{N}$ via inoculation with $A$. brasilense could be an effective alternative in maintaining the survival of the individual generations, and minimizing the effects of climate constraints on the stability of the tiller population, during the seasons of autumn/ winter and early spring.

Rashid (2014) demonstrated the positive effects of inoculation with $A$. brasilense over the entire length, area, and volume of the roots of wheat genotypes ( $T$. aestivum) in the initial establishment phase. However, these effects decreased over time, and therefore, this strategy did not result in a higher biomass or grain production. According to the author, the promising effects of plant growth promoting rhizobacteria (PGPB) in the field can be limited by factors that influence their survival and activity in the rhizosphere.
Accordingly, experiments are required immediately, to evaluate the responses of the forage grasses throughout the year, to determine the possible benefits of inoculation with $A$. brasilense and identify the periods of the year that best suit its strategic implementation, so it can favor the tillering, population stability, and forage production.

\section{CONCLUSIONS}

Inoculation with Azospirillum brasilense did not affect the population density or the tillering dynamics in Marandu palisade grass swards throughout the growing season.

The population density and tillering dynamics revealed a seasonal pattern influenced by climate variables.

\section{REFERENCE}

ABAHMANI, I.; THOM, E.R.; MATTHEW, C. et al. Tiller dynamics of perennial ryegrass cultivars derived from different New Zealand ecotypes: effects of cultivar, season, nitrogen fertilizer, and irrigation. Aust. J. Agric. Res., v.54, p.803-817, 2003.

ALVARES, C.A.; STAPE, J.L.; SENTELHAS, P.C. et al. Köppen's climate classification map for Brazil. Meteorol. Z., v.22, p.711-728, 2013.

CAMINHA, F.O.; SILVA, S.C.; PAIVA, A.J. et al. Estabilidade da população de perfilhos de capim Marandu sob lotação contínua e adubação nitrogenada. Pesqui. Agropec. Bras., v.45, p.213220, 2010.

CAMPOS, D.B.; RESENDE, A.S.; ALVEZ, B.J. et al. Contribuição da fixação biológica de nitrogênio para a cultura de arroz sob inundação. Agronomia, v.37, p.1-46, 2003.

CASANOVAS, E.M.; BARASSI, C.A.; SUELDO R.J. Azospirillum inoculation mitigates water stress effects in maize seedlings. Cereal Res. Commun., v.30, p.343-350. 2002.

DÍAZ-ZORITA, M.; FERNÁNDEZ-CANIGIA, M.V. Field performance of a liquid formulation of Azospirillum brasilense on dry land wheat productivity. Eur. J. Soil Biol., v.45, p.3-11, 2009. 
DOBBELAERE, S.; VANDERLEYDEN, J.; OKON; Y. Plant growth-promoting effects of diazotrophs in the rhizosphere. Crit. Rev. Plant Sci., v.22, p.107-149, 2003.

FIALHO, C.A.; SILVA, S.C.; GIMENES, F.M.A. et al. Tiller population density and tillering dynamics in Marandu palisade grass subjected to strategies of rotational stocking management and nitrogen fertilization. Acta Sci. Anim. Sci., v.34, p.245-251. 2012.

HODGSON, J. Grazing management: science into pratice. New York: John Wiley, Longman Scientific and Technical, 1990. 203p.

HUNGRIA, M.; CAMPO, R.J.; SOUZA, E.M. Inoculation with selected strains of Azospirillum brasilense and A. lipoferum improves yields of maize and wheat in Brazil. Plant Soil., v.331, p.413-425, 2010.

KENWARD, M.; ROGER, J. Small sample inference for fixed effects from restricted maximum likelihood. Biometrics, v.53, p.983997, 1997.

LARA, M.A.S.; PEDREIRA, C.G.S. Respostas morfogênicas e estruturais de dosséis de espécies de braquiária. Pesqui. Agropecu. Bras., v.46, p.760-767, 2011.

MATTHEW, C.; ASSUERO, S.G.; BLACK, C.K. et al. Tiller dynamics of grazed swards. In: LEMAIRE, G.; HODGSON, J.; MORAES, A.P.C.F. et al. (Eds.). Grassland ecophysiology and grazing ecology. Wallingford: CABI Publishing, 2000. 432p.

RASHID, K.N. The response of wheat genotypes to inoculation with Azospirillum Brasilense. 2014. 249f. Tese (Doctoral) - Faculty of Agriculture and Environment, University of Sydney, AU.

SALA, V.M.R.; CARDOSO, E.J.B.N.; FREITAS, J.D. et al. Wheat genotypes response to inoculation of diazotrophic bacteria in field conditions, Pesqui. Agropecu. Bras., v.42, p.833842,2007
SBRISSIA, A.F. Morfogênese, dinâmica do perfilhamento e acúmulo de forragem em pastos de capim marandu sob lotação contínua. 2004. 171f. Tese (Doutorado em Agronomia) - Escola Superior de Agricultura Luiz de Queiroz, Universidade de São Paulo, Piracicaba, SP.

SILVA, D.M.; FRIES, R.; ANTONIOLLI, Z.I. et al. Bactérias diazotróficas em solo cultivado com arroz irrigado (Oryza sativa L.). Rev. Bras. Agrocienc., v.10, p.467-474, 2004.

SILVA, S.C.; NASCIMENTO JÚNIOR, D.; EUCLIDES, V.B.P. Pastagens: conceitos básicos, produção e manejo. Viçosa: UFV, 2008. $115 \mathrm{p}$.

SILVA, S.C.; SBRISSIA, A.F.; PEREIRA, L.E.T. Ecophysiology of C4 forage grasses understanding plant growth for optimising their use and management. Agriculture, v.5, p.598$625,2015$.

SMITH, R.L.; SCHANK, S.C.; MILAM, J.R.; BALTENSPERGER, A.A. Responses of Sorghum and Pennisetum species to the $\mathrm{N}_{2}$ Fixing Bacterium Azospirillum Brasilense. Appl. Environ. Microbiol., v.47, p.1331-1336, 1984.

SOUZA, P.T.; BANYS, V.L.; DIAS, M. et al. Tillering of Brachiaria brizantha cv. Marandu inoculated with Azospirillum Brasilense or fertilized with nitrogen. In: INTERNATIONAL RANGELAND CONGRESS, 10, 2016, Saskatton. Proceeding... Saskatton: [s.n.] 2016. p.1-2 (Abstract).

STATISTICAL analysis system. Version 8.2. Cary: SAS Institute, 2013.

STEENHOUDT, O.; VANDERLEYDEN， J. Azospirillum, a free-living nitrogen-fixing bacterium closely associated with grasses: genetic, biochemical and ecological aspects. Fems Microbiol. Rev., v.24, p.487-506, 2000.

TAIZ, L.; ZEIGER., E. Fisiologia vegetal. 5.ed. Porto Alegre: Rio Grande do Sul, ArtMed, 2013. 918p.

TILAK, K.V.B.R.; ANNAPURNA, K. Role of Azospirillum in the improvement of crop production and plant nutrition. Proc. Indian Natl. Sci. Acad., v.59, p.315-315, 1993. 